\title{
Intermittent Renewable Energy Sources: The Role of Energy Storage in the European Power System of 2040
}

\author{
Henrik Zsiborács ${ }^{1}$, Nóra Hegedúsné Baranyai ${ }^{1, *}$, András Vincze ${ }^{2}$, László Zentkó ${ }^{3}$, \\ Zoltán Birkner ${ }^{4}$, Kinga Máté ${ }^{5}$ and Gábor Pintér ${ }^{1}$ \\ Department of Economic Methodology, University of Pannonia, Georgikon Faculty, 8360 Keszthely, Hungary \\ Department of Foreign Languages, Georgikon Faculty, University of Pannonia, 8360 Keszthely, Hungary \\ PANNON Pro Innovations Ltd., 1021 Budapest, Hungary \\ Nagykanizsa Campus, University of Pannonia, 8800 Nagykanizsa, Hungary \\ Wolf Theiss Faludi Erős Law Firm, 1085 Budapest, Hungary \\ * Correspondence: baranyai@georgikon.hu; Tel.: +36-30-373-8550
}

Received: 21 May 2019; Accepted: 18 June 2019; Published: 26 June 2019

check for updates

\begin{abstract}
Global electricity demand is constantly growing, making the utilization of solar and wind energy sources, which also reduces negative environmental effects, more and more important. These variable energy sources have an increasing role in the global energy mix, including generating capacity. Therefore, the need for energy storage in electricity networks is becoming increasingly important. This paper presents the challenges of European variable renewable energy integration in terms of the power capacity and energy capacity of stationary storage technologies. In this research, the sustainable transition, distributed generation, and global climate action scenarios of the European Network of Transmission System Operators for 2040 were examined. The article introduces and explains the feasibility of the European variable renewable energy electricity generation targets and the theoretical maximum related to the 2040 scenarios. It also explains the determination of the storage fractions and power capacity in a new context. The aim is to clarify whether it is possible to achieve the European variable renewable energy integration targets considering the technology-specific storage aspects. According to the results, energy storage market developments and regulations which motivate the increased use of stationary energy storage systems are of great importance for a successful European solar and wind energy integration. The paper also proves that not only the energy capacity but also the power capacity of storage systems is a key factor for the effective integration of variable renewable energy sources.
\end{abstract}

Keywords: solar energy; wind energy; energy storage; renewable energy integration; Europe

\section{Introduction}

\subsection{Changes in the Spread of Photovoltaic and Wind Energy Technologies in the World}

Today's boost in energy demand and shift towards a low-carbon economy brings about an increased need for the deployment of cutting-edge technologies and services in the energy sector [1,2]. Addressing climate change and the excessive greenhouse gas (GHG) emissions are among the top urging issues at a global level. On the pathway towards a low-carbon future, the use of renewable energies will undoubtedly have a key role [3,4]. Variable renewable energy (VRE) sources, such as photovoltaic (PV) energy, may serve as a remedy in order to mitigate the adverse effect of the above factors, given their sustainable, clean, and ecofriendly nature [5-7]. Current ambitions targeting the reduction of GHG-emissions attribute a growing importance to the electricity sector alongside a more distributed generation (DG). When it comes to tackling climate change, PV and wind energy 
technologies will be key drivers in paving the way towards sustainability and energy conservation. However, today the integration of VRE sources poses a challenge to be addressed for the successful decentralization of the electricity network. From the point of view of power quality, PV and wind energy have some disadvantages. The intermittent nature of VRE sources and distributed generation remain a challenge to grid operators when scheduling power generation. On the other hand, distributed energy generation may enhance the further spread of smart grids and micro grids and, therefore, ensure a greater share of clean energy in the energy mix [8-14].

PV and wind technologies play a key role in the shift towards green growth, a low-carbon economy, and a greater share of renewables in the energy mix [15]. In the last decade, support schemes such as the feed-in-tariff system, the declining initial capital expenditure due to the boost in innovation, and technology have proved to be essential factors that underpin this phenomenon [16-18]. Statistics show a considerable growth of PV and wind energy globally; $7.5 \%$ of the total $26.5 \%$ share of renewables in electricity generation was produced by VRE installations in 2017. In the same year, the global built-in PV and wind capacity amounted to $941 \mathrm{GW}$ (Figure 1). The key players of the PV electricity market were China (131.1 GW), followed by the EU (108 GW), the USA (51 GW), and Japan (49 GW). China (188.4), the EU (168.7 GW), and the USA ( $89 \mathrm{GW}$ ) were also leaders in terms of wind capacity, followed by India with a share of $32.8 \mathrm{GW}[17,19]$.

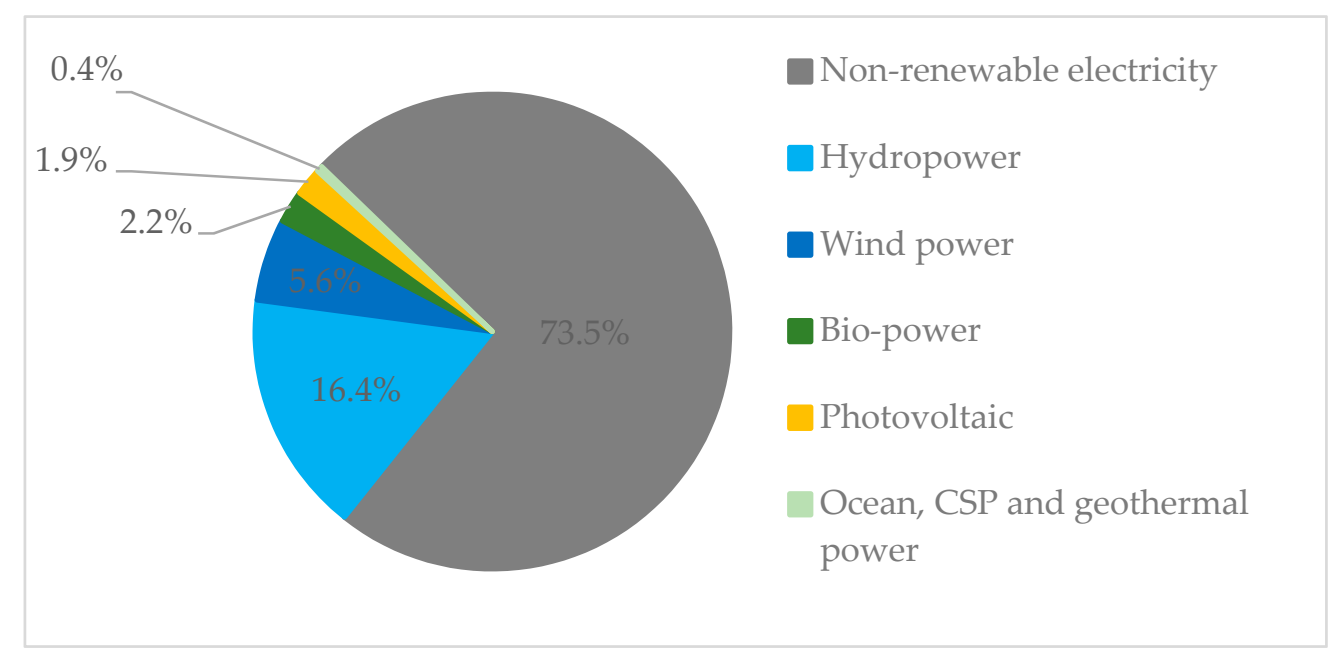

Figure 1. Estimated renewable energy share of global electricity production, 2017, based on [17].

\subsection{Energy Challenges with the Spread of Variable Renewable Energy Sources}

Today, the integration of VRE sources into the electricity grid is one of the crucial issues to be addressed at an international and national level. For example, the European Union (EU) has set the ambitious goal to cut its overall GHG emission by more than $80 \%$ by 2050 , as well as to become the global leader in the usage of renewable energy sources (RES). To achieve this goal, member states shall endeavor in the coming years to significantly increase the share of intermittent renewable energy sources in their energy mix. By integrating more VRE sources into the European grid system, it will be essential to tackle the need for a more flexible electricity grid. Subsequently, cost competitive energy storage technologies will be drivers in creating the necessary secure balance between distributed and centralized electricity generation and the integration of a higher share of viable renewables such as solar and wind energy [20]. However, due to their variable power generation nature, the integration of $\mathrm{PV}$ and wind power into the electricity grid is a challenge, since the existing grids and their capacities were established to comply with less or non-variable energy sources, dispatchable power generation, and predictable load peaks. In general, today's electricity grids are able to handle a low increase in load as a result of newly built-in VRE capacities, but a massive load increase can cause discrepancies in the macro energy system. In order to mitigate and successfully tackle regional differences arising from 
the variable solar and wind potentials, the electricity system of the new era should not only be flexible but also possess a sufficient backup capacity. The flexibility of the grid is an essential factor in handling network constraints caused by VRE generation during the peak hours of demand. On the other hand, storage capacity may be beneficial when there is an incline in sunshine hours and wind speed [21-24].

\subsection{The Importance of Energy Storage Systems and their Future Role}

According to the European vision, the energy system will rely significantly on renewables by 2040, more specifically on non-dispatchable and VRE power, which at the same time will bring about the partial decentralization of the energy system [25-27]. The optimal share of VRE sources in the energy mix depends on various factors. The flexibility of the grid, the back-up capacity, the quality and capacity of the transmission system [28-31], as well as load performance characteristics [32-34] and the actual local weather patterns may determine the volume of VREs that can be safely fed into the system [35-37]. A potential solution to compensate for the uncertainty arising from the variable nature of VREs is to upgrade and enhance the overall flexibility of the electricity grid. By adding storage capacity to the energy system, greater flexibility can be achieved through the provision of a back-up potential for shaving of peak loads or filling valleys [35,36,38].

Today, there exist multiple storage technologies and solutions that are able to compensate for the intermittent nature of VRE sources (Figure 2), namely electro-chemical energy storage, electro-mechanical energy storage, electrical energy storage, thermal storage, and chemical energy storage. The key solutions for large-scale energy storage include compressed air storage, pumped hydro storage (PHS), molten salt thermal storage, or flow batteries (Figure 3). The details of the specific features of these energy storage technologies, however, are not included in this manuscript. The abbreviations for all technologies are listed in the abbreviations section. Overall, the global energy storage capacity including both stationary and grid-connected capacities amounted to approximately 159 GW, of which 153 GW was PHS in 2017 [17,39].
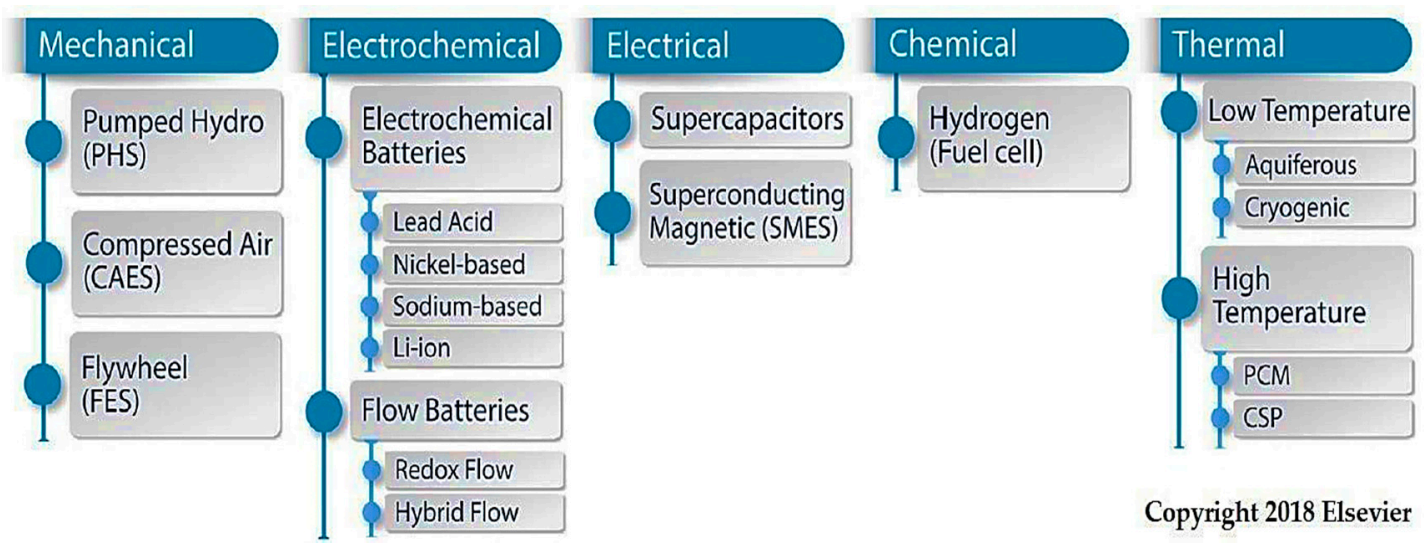

Figure 2. Classification of energy storage technologies by the form of stored energy [39]. 


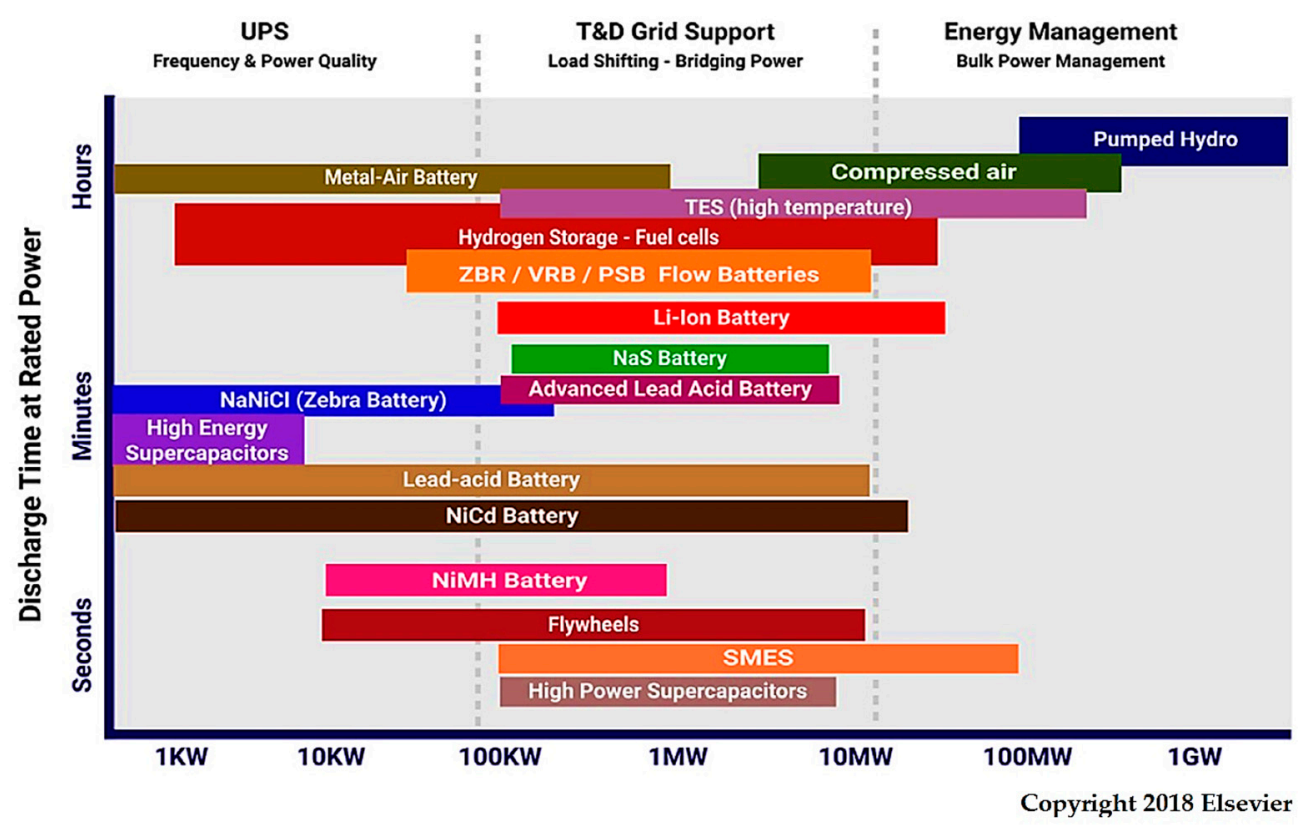

Figure 3. Energy storage technologies by discharge time and power capacity [39].

At the beginning of 2017, the global, overall, new advanced energy storage capacity amounted to around $5.9 \mathrm{GW}$. In this year, the energy these energy storage technologies put into operation accounted for approximately $0.5 \mathrm{GW}$ of the final total. The share of electrochemical storage solutions (battery) had increased considerably, by $0.4 \mathrm{GW}$, at the beginning of 2017 up to a total of $2.3 \mathrm{GW}$ [17]. Due to its user-friendly, economical nature and rather simple deployment, battery storage is one of the most popular options when considering energy storage solutions both at a domestic and industrial level. The use cases of energy storage are shown in Figure 4, but an explanation of these features is not provided in the present paper $[9,14,40]$.

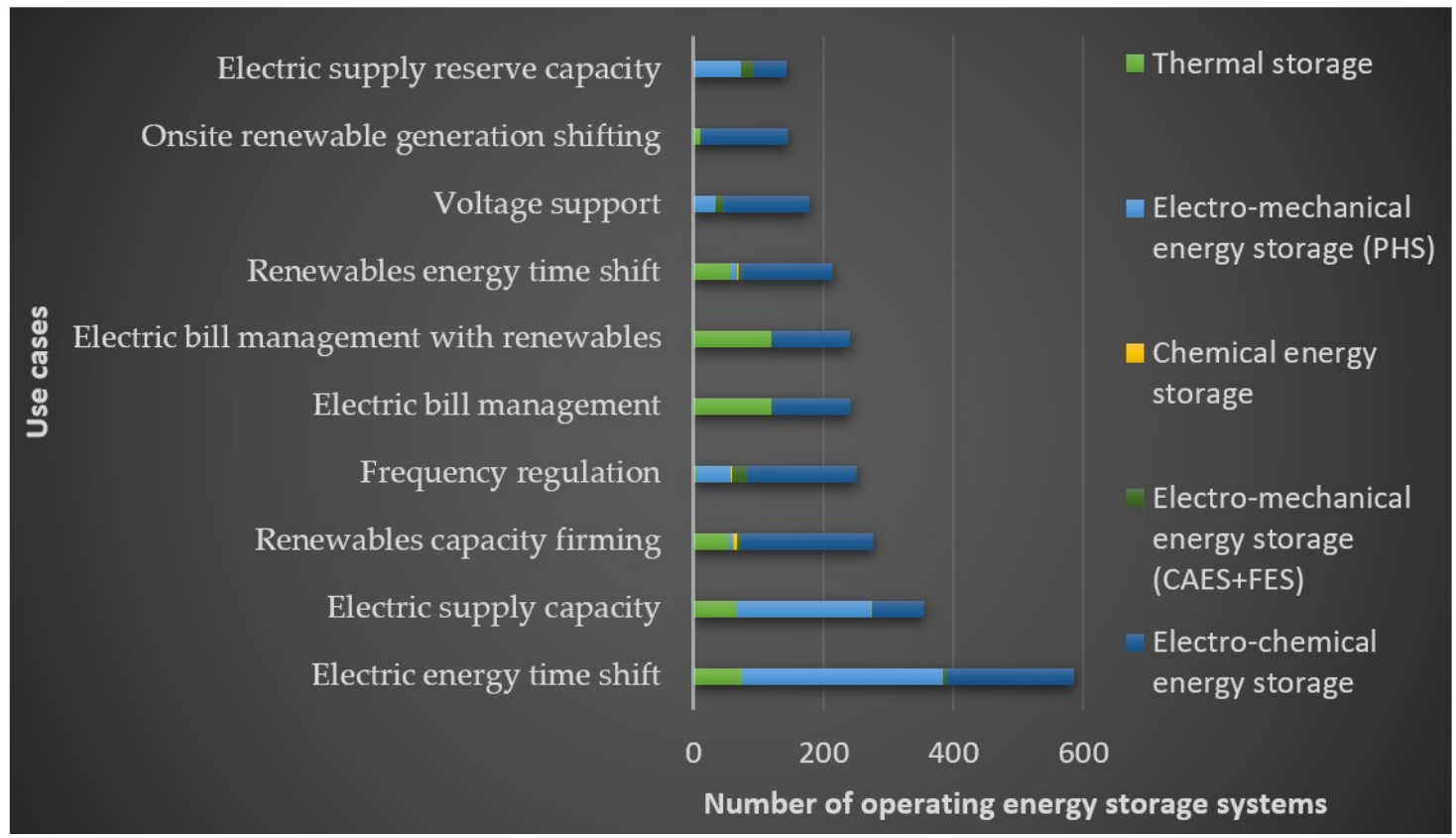

Figure 4. The 10 most common use cases of energy storage systems until August 16, 2016, based on [9] (Projects can have multiple use cases). 
Compared to the approximately 4.67 TWh of 2017, if the current trends persist and the share of VREs in the global energy mix doubles, there will be a considerable growth in the overall energy storage capacity by 2030 up to about 6.62-15.89 TWh [8]. However, this increase is slightly unpredictable at present. According to the relevant forecasts, the share of PHS technologies will fall to approximately $90 \%$ of the overall installed storage capacity by 2030. In the meantime, the declining production cost of storage appliances will bring about an explosive development of cutting-edge battery technologies and the diversification of their possible uses, inter alia both at grid and self-consumption level (e.g., rooftop solar PV). Based on current projections and future scenarios [10], non-pumped hydroelectricity storage will grow from an estimated 162 GWh in 2017 to 5.8-8.4 TWh by 2030. Key drivers behind the boost in the energy storage market will be behind-the-meter and utility-scale solutions. The battery capacity of stationary applications is expected to increase from the estimated 11 GWh in 2017 up to about 100-421 GWh by 2030. Using battery electricity storage integrated into small-scale PV systems will be one of the most common and marketable ways of battery deployment in the period until 2030. In the near future, the economic viability of stationary battery electricity storage solutions is expected to drastically advance across Europe and beyond due to beneficial factors, such as increased residential and commercial electricity rates, better support schemes (e.g., relatively low feed-in-tariffs), and competitive cost structures. Moreover, alongside with the spread of favorable support schemes for VRE's, new markets for additional products and services are also expected to appear [8-14].

\subsection{European Electricity Consumption and Energy Storage Aspects}

According to data from the European Network of Transmission System Operators for Electricity (ENTSO-E), in 2017 the European total electricity consumption amounted to 3,329 TWh, showing a moderate increase $(+0.2 \%)$ compared to the previous year's data. In the same year, the peak demand on the electricity grid was measured on 18 January and amounted to 542 GW (4 GW less than in 2016). With regard to the net generating capacity (NGC), the figures show a slight decline for nuclear $(-2.3 \%)$ and fossil fuels (-3.1\%) from 2016 to 2017 . On the other hand, the net generating capacity for solar and wind energy grew by $6.1 \%$ and $9.8 \%$ in the same period. The thirty-six member countries of ENTSO-E are Austria, Albania, Bosnia and Herzegovina, Belgium, Bulgaria, Switzerland, Cyprus, Czech Republic, Germany, Denmark, Estonia, Spain, Finland, France, United Kingdom, Greece, Croatia, Hungary, Ireland, Iceland, Italy, Lithuania, Luxembourg, Latvia, Montenegro, Macedonia, Netherlands, Norway, Poland, Portugal, Romania, Serbia, Sweden, Slovenia, Slovakia, and Turkey. It should, however, be noted that Albania (member since March 2017) and Turkey (observer member) are not included in the statistics. The summary data are shown in Tables 1 and 2 [41].

Table 1. European electricity consumption and maximum peak loads between 2013 and 2017 [41].

\begin{tabular}{cccccc}
\hline Year & $\mathbf{2 0 1 3}$ & $\mathbf{2 0 1 4}$ & $\mathbf{2 0 1 5}$ & $\mathbf{2 0 1 6}$ & $\mathbf{2 0 1 7}$ \\
\hline Electricity consumption [tWh] & 3293 & 3241 & 3301 & 3322 & 3329 \\
\hline Maximum peak load [GW] & 516 & 511 & 520 & 546 & 542 \\
\hline
\end{tabular}


Table 2. Evolution of electricity consumption between 2016 and 2017 in Europe [41].

\begin{tabular}{|c|c|}
\hline Country & $\begin{array}{c}\text { Change of Electricity Consumption between } 2016 \\
\text { and } 2017 \text { in Europe [\%] }\end{array}$ \\
\hline United Kingdom & -3.0 \\
\hline Germany & -1.8 \\
\hline Austria & -1.2 \\
\hline Denmark & -1.1 \\
\hline Latvia & -0.6 \\
\hline France & -0.3 \\
\hline Luxembourg & 0.0 \\
\hline Norway & 0.2 \\
\hline Sweden & 0.2 \\
\hline Netherlands & 0.4 \\
\hline Switzerland & 0.4 \\
\hline Finland & 0.6 \\
\hline Portugal & 0.7 \\
\hline Belgium & 0.8 \\
\hline Ireland & 1.0 \\
\hline Macedonia & 1.1 \\
\hline Greece & 1.2 \\
\hline Spain & 1.2 \\
\hline Estonia & 1.4 \\
\hline Cyprus & 1.6 \\
\hline Bulgaria & 1.9 \\
\hline Serbia & 2.1 \\
\hline Bosnia and Herzegovina & 2.2 \\
\hline Czech Republic & 2.5 \\
\hline Romania & 2.5 \\
\hline Hungary & 2.6 \\
\hline Lithuania & 2.6 \\
\hline Poland & 2.6 \\
\hline Slovenia & 2.8 \\
\hline Croatia & 3.2 \\
\hline Iceland & 3.2 \\
\hline Slovakia & 3.2 \\
\hline Italy & 3.9 \\
\hline Montenegro & 5.6 \\
\hline Albania & no information \\
\hline Turkey & no information \\
\hline
\end{tabular}

The overall net generating capacity from renewable electricity sources (RES) (without hydro energy) has a share of approximately $30 \%$ of the total NGC. Meanwhile, electricity produced from hydro power showed a considerable decline caused by decreased water discharge $(9.3 \%)$. On the regional level, the energy demand shows disparities. While the energy demand is extensively growing in Eastern Europe and shows a moderate growth in the Hispanic Peninsula, there is a slight decline in electricity consumption in some European countries, such as Germany, Austria, and Great Britain. However, the Central European countries (except for Germany and Austria) remain stable in their demand [41]. In Europe the installed PHS capacity in 2017 reached 50.5 GW (approx. 1.9 TWh energy capacity based on $[11,40,42-44])$, of which a capacity of more than $59 \%$ was found in 5 countries, namely Italy, France, Germany, Austria, and Spain (Figure 5). Based on the ENTSO-E scenarios, the PHS capacity increase is expected to be in the range of $58-76 \mathrm{GW}$ by $2040[27,45]$. At the beginning of 2017 other storage technologies represented about $1.3 \%$ of the total storage capacity based on thirty ENTSO-E countries $[9,46]$. 


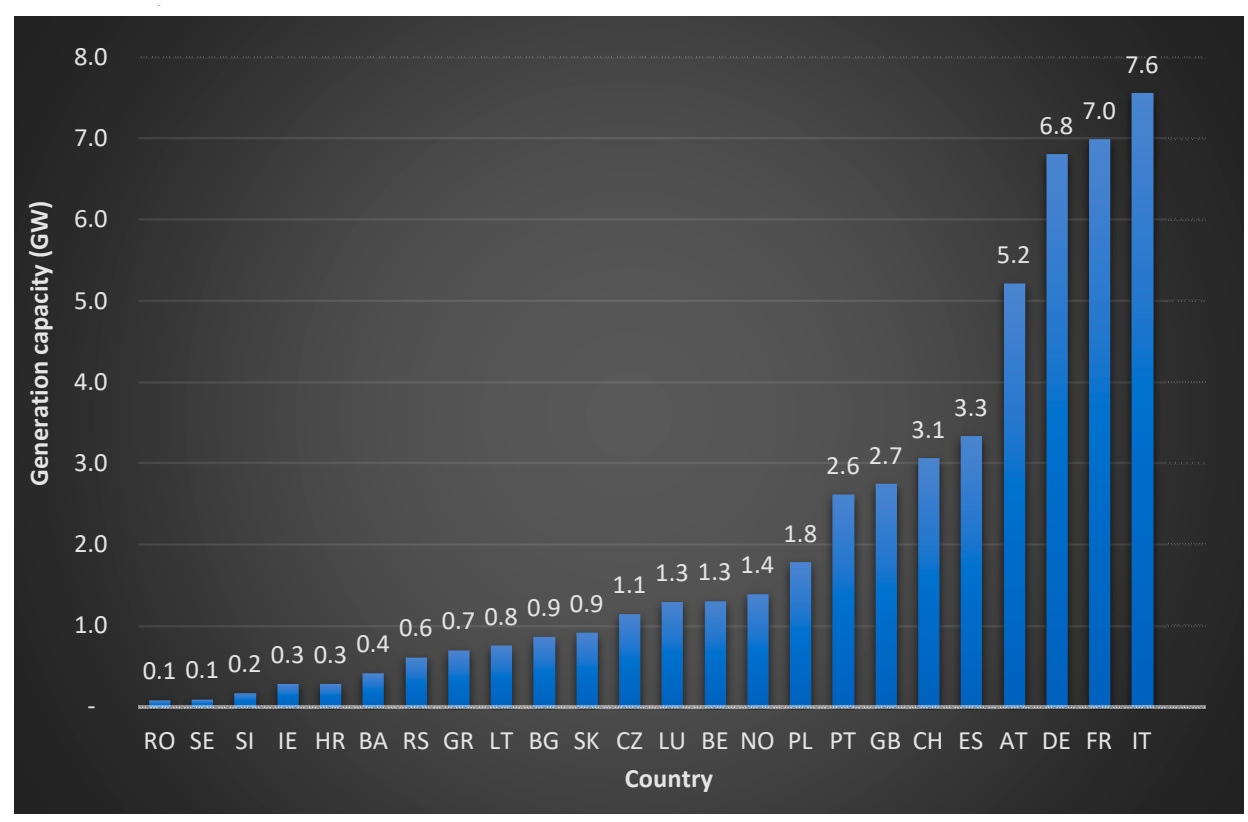

Figure 5. European installed pumped hydro storage (PHS) generation capacity in 2017 based on [45].

\section{Material and Methods}

In the research project, the 2040 scenarios titled Sustainable Transition (ST), Distributed Generation (DG), and Global Climate Action (GCA) developed by the European Network of Transmission System Operators were examined in relation to the VRE integration targets and the theoretical maximum considering the technology-specific storage aspects. In the modelling we combined only the main findings of the manuscripts that examined the European level and the general, global conclusion from Blanco-Faaij (2018) [47]. These manuscripts also analyzed the power capacity and/or the energy capacity of stationary storage technologies for secure European grid balancing. Thus, the first common point of the analyzed manuscripts is the provision of the balance of the European grid system by stationary storage technologies. Other key components for analysis at the European level were annual demand, VRE penetration, and energy storage capacity, which can be well defined. This approach was published by Blanco-Faaij in 2018 [47]. VRE gross electricity generation is a percentage of the total electricity demand and this value can also be easily determined. According to the authors, the carefully selected articles complement each other's results, and the conclusions of the manuscripts were applied to the European grid sector.

\subsection{Description of the ENTSO-E Scenarios}

The ST scenario seeks economical, quick, and sustainable $\mathrm{CO}_{2}$ reduction by replacing lignite and coal by gas in the power sector. In this case energy generation by gas is popular due to the relatively cheap global gas prices and the strong growth of bio-methane. A regulatory framework in place decreases the use of coal power plants. Gas-based energy generation largely provides the necessary flexibility to balance renewables in the power system. In this storyline, climate action is achieved with a mixture of emission trading, national regulation, subsidies, and schemes [27].

In the DG scenario, significant leaps in the innovation of commercial/residential storage technologies and small-scale generation are a key driver in climate action. This case represents a more decentralized development with focus on end-user technologies. Smart technologies, PV systems, electric vehicles, and dual-fuel appliances allow consumers to switch energy depending on market conditions. Biomethane growth is strong as connections to distribution systems grow, utilizing local feedstocks. In this storyline, the electricity demand flexibility is substantially increased, both in industrial and residential solutions, helping electric power adequacy. Wintertime, however, with 
low solar availability and high heating needs remains a challenge, since batteries cannot be used for seasonal storage [27].

The GCA scenario represents a global effort towards full speed decarbonization. The emphasis is on renewables and nuclear energy in the power sector. Commercial and residential heat becomes more electrified, leading to a steady decline in demand for gas in this sector. The decarbonization of transportation is achieved through gas and electric vehicle growth and the power-to-gas production sees its strongest development within this scenario. Gas power plants provide the flexibility needed within the power market, helping facilitate intermittent renewable technologies within it [27]. The European electricity consumption and maximum peak load features, production capacities and generation in 2040 based on the examined scenarios are shown in Table 3 and Figure 6. These input data were important for modeling.

Table 3. European electricity consumption and maximum peak load features in 2040 based on the examined scenarios [27].

\begin{tabular}{cccc}
\hline Year & 2040, ST & 2040, DG & 2040, GCA \\
\hline Electricity demand [TWh] & 4030 & 4450 & 4100 \\
\hline Maximum peak load [GW] & 650 & 730 & 690 \\
\hline $\begin{array}{c}\text { VRE annual electricity generation } \\
\text { compared to the demand [TWh] }\end{array}$ & 1600 & 2250 & 2430 \\
\hline $\begin{array}{c}\text { VRE annual electricity generation } \\
\text { target compared to the demand [\%] }\end{array}$ & 39.7 & 50.6 & 59.3 \\
\hline
\end{tabular}
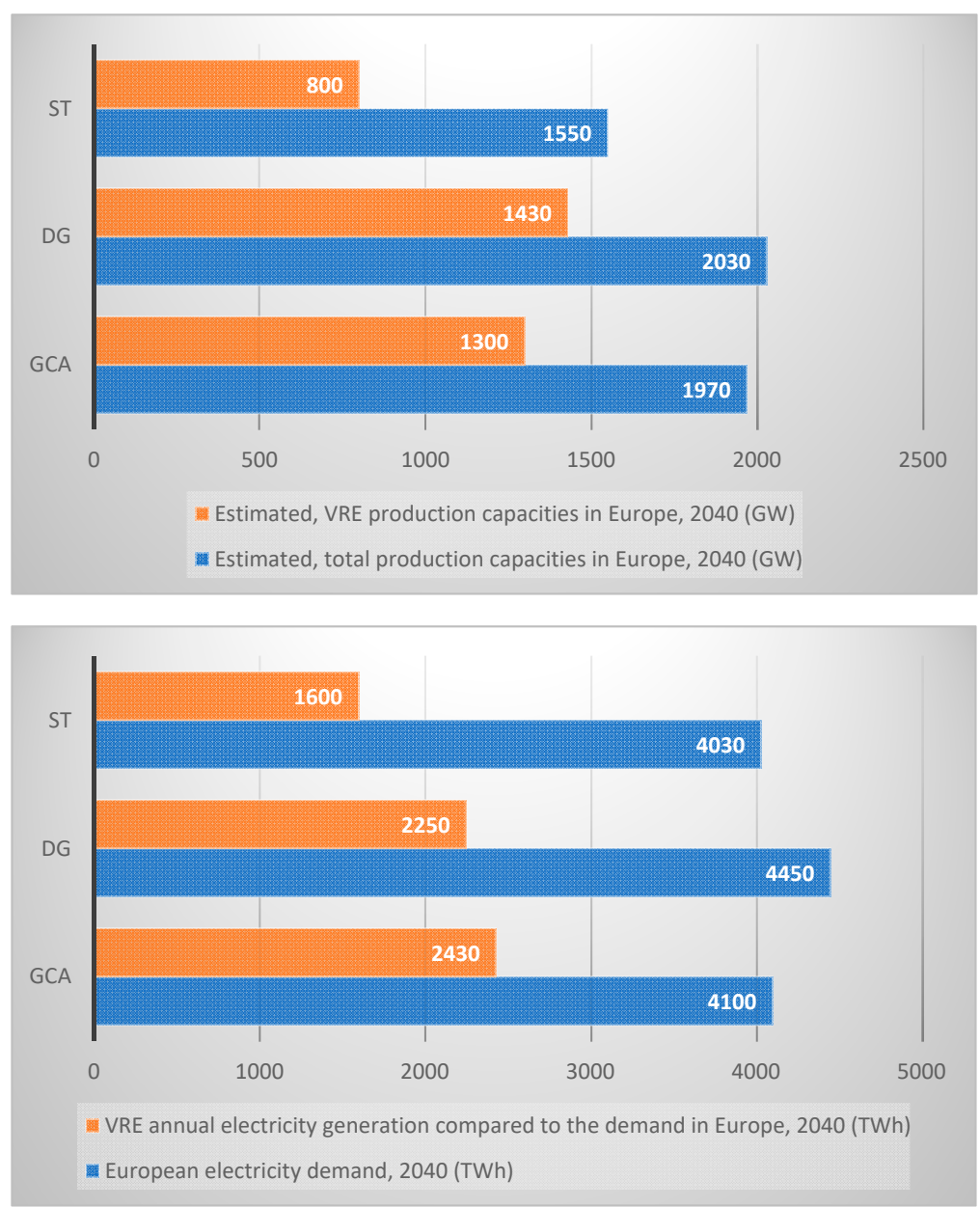

Figure 6. Installed production capacities and generation in Europe based on the 2040 scenarios [48]. 
The ENTSO-E scenarios take into account the impact of EV penetration in the electricity demand. However, it is stationary storage technologies that ensure that the potential uncertainty of the power supply resulting from VRE penetration is eliminated [27].

\subsection{European Energy Storage Case Studies for VRE Integration}

An important variable that defines the energy storage capacity requirement is the energy production from the VRE sources in the energy mix [47,49]. Several studies were reviewed to estimate the European stationary storage size as a fraction of VRE penetration and annual demand. With the solution, it is possible to determine the average energy storage fraction requirements expressed in energy storage capacity (TWh). This refers to the amount of energy that can be stored at the same time and not energy delivered throughout a year. The energy storage fraction and the energy storage capacity are relative numbers to compare across studies. In this manuscript a polynomial regression model was developed in MATLAB by combining the logic of 7 studies $[13,22,47,50-53]$. These sources are meta-analyses, in which hundreds of manuscripts were analyzed and evaluated. The model calculates the average energy storage fraction in the context of VRE gross electricity generation, expressed as a percentage of the total electricity demand. The issue of the energy storage fraction has been analyzed in many studies in the context of VRE energy production. Blanco and Faaij [47] summarize the factors that determine this fraction based on 79 sources and conclude that there are significant differences between countries (Tables 4 and 5). For this reason, the model proposes that the storage requirement should be examined at the European level, defining an average value. Tables 4 and 5 show the summarized VRE penetrations of 10-100\%. A general conclusion by Blanco and Faaij [47] is that even for high VRE penetrations of $90-95 \%$, the storage fraction is at most $1.5 \%$ of the annual demand, while that for a VRE penetration of $100 \%$ this share is highly uncertain. However, it should be noted that according to $[13,51-53]$, there is no need for a high degree of storage flexibility for a VRE percentage of $40-50 \%$. The figures presented in Table 4 are listed in an increasing order of 'VRE penetration', while Table 5 displays the data in the increasing order of the 'energy storage fraction'.

Table 4. Recommended annual storage features in Europe, with less than $100 \%$ VRE penetration, based on [47].

\begin{tabular}{|c|c|c|c|c|c|}
\hline Country & $\begin{array}{c}\text { Annual Demand } \\
{[\mathrm{TWh}]}\end{array}$ & $\begin{array}{c}\text { VRE Penetration } \\
{[\%]}\end{array}$ & $\begin{array}{l}\text { Energy Storage } \\
\text { Capacity [TWh] }\end{array}$ & $\begin{array}{c}\text { Energy Storage } \\
\text { Fraction [\%] }\end{array}$ & Ref. \\
\hline Europe & 3746 & 16 & 1.15 & 0.0308 & {$[22,47]$} \\
\hline Spain & 375 & 25 & 0.66 & 0.18 & [54] \\
\hline Netherlands & 123 & 28.3 & 0.05 & 0.04 & [55] \\
\hline West Europe & 4647 & 30 & 2.4 & 0.05 & [56] \\
\hline UK & $\sim 700$ & 30 & 0.06 & 0.01 & [57] \\
\hline Ireland & 32.7 & 34.5 & 0.07 & 0.21 & [58] \\
\hline Germany & 478 & 38.6 & 0.06 & 0.01 & [59] \\
\hline Europe & 4670 & 48 & 2.08 & 0.0445 & {$[22,47]$} \\
\hline Germany & 562 & 50 & 3.5 & 0.62 & [13] \\
\hline Germany (Region) & 53 & $20-50$ & 0.15 & 0.28 & [60] \\
\hline Greece & 88.3 & 50 & $0.4-1.4$ & 1.02 & [61] \\
\hline Austria & 83 & 55 & 0.2 & 0.24 & {$[62]$} \\
\hline UK & 300 & 60 & 0.1 & 0.03 & [63] \\
\hline Spain & 420 & 60 & $0.6-2.2$ & 0.33 & [54] \\
\hline Germany & 2030 & 66 & 18 & 0.89 & {$[31]$} \\
\hline Belgium & 268 & 80 & 1.3 & 0.32 & {$[64]$} \\
\hline Denmark & 41 & 80 & 0.66 & 1.61 & {$[65]$} \\
\hline Germany & 413 & 80 & $0.9-1.3$ & 0.27 & [59] \\
\hline Germany & $\sim 600$ & 80 & $7-8$ & 1.25 & [66] \\
\hline Germany & 586 & 80 & 0.5 & 0.09 & [67] \\
\hline Germany (Region) & 22.7 & 80 & 0.184 & 0.81 & [68] \\
\hline Ireland & 45 & 80 & 2.8 & 6.00 & [58] \\
\hline Europe & 4900 & 80 & 50 & 1.02 & {$[50]$} \\
\hline $\begin{array}{l}\text { General, global } \\
\text { conclusion }\end{array}$ & - & 90-95 & - & 1.5 & [47] \\
\hline
\end{tabular}


Table 5. Recommended annual storage features in Europe, with a renewable energy sources (RES) penetration of $100 \%$ based on [47].

\begin{tabular}{cccccccc}
\hline Region & Year & $\begin{array}{c}\text { Annual } \\
\text { Demand } \\
{[\text { [TWh] }}\end{array}$ & $\begin{array}{c}\text { Wind/Solar } \\
{[\%]}\end{array}$ & $\begin{array}{c}\text { Energy } \\
\text { Storage } \\
\text { Capacity } \\
{[\text { TWh] }}\end{array}$ & $\begin{array}{c}\text { Energy Storage, } \\
\text { Power Capacity } \\
{[\text { [GW] }}\end{array}$ & $\begin{array}{c}\text { Energy } \\
\text { Storage } \\
\text { Fraction } \\
{[\%]}\end{array}$ & Ref. \\
\hline Ireland & 2050 & 125 & $13 / 2$ & 0.24 & 10 & 0.19 & {$[69]$} \\
\hline Europe & 2050 & 4200 & $73 / 21$ & 13.5 & - & 0.32 & {$[70]$} \\
\hline France & 2050 & 425 & $40 / 17$ & 3 & 3 & 0.71 & {$[71]$} \\
\hline Europe & - & 3240 & $55 / 45$ & 25 & 360 & 0.77 & {$[37]$} \\
\hline Germany & 2050 & 475 & $60 / 40$ & 9.1 & - & 1.92 & {$[72]$} \\
\hline $\begin{array}{c}\text { Germany } \\
\text { (Region) }\end{array}$ & 2030 & 19.9 & $55 / 40$ & 0.53 & 1.5 & 2.66 & {$[68]$} \\
\hline UK & 2030 & 900 & $55 / 6$ & 27 & 35 & 3.00 & {$[73]$} \\
\hline Greece & 2050 & 55.7 & $100 / 0$ & 2 & $0.2-0.3$ & 3.59 & {$[74]$} \\
\hline Europe & - & 3400 & $55 / 45$ & 216 & 65 & 6.35 & {$[75]$} \\
\hline Europe & 2007 & 3240 & $55 / 45$ & $400-480$ & 400 & 13.58 & {$[35]$} \\
\hline Europe & - & - & - & - & - & $20-40$ & {$[76]$} \\
\hline
\end{tabular}

\section{Results}

\subsection{Determination of the European Storage Fractions}

The issue of storage fractions has been analyzed in many studies in the context of gross VRE electricity generation. In this manuscript, a polynomial regression model was developed in MATLAB by combining the logic of seven studies [13,22,47,50-53]. Blanco and Faaij [47] summarize the factors that determine the mentioned fractions based on 79 sources and conclude that there are significant differences between countries. Other sources $[22,47,50]$ were suitable for investigating the storage fractions as a function of gross VRE electricity generation at the European level. These baseline values have been applied to modelling:

- European storage fraction: 0.0308-0.0372\%; VRE penetration: $16-45 \%$ [22].

- European storage fraction: $1.02 \%$; VRE penetration: $80 \%$ [50].

- European storage fraction: $1.5 \%$; VRE penetration: 95\% [47].

From the reviewed studies it became evident that the 40-50\% energy production share from VRE in the European power grid sector is a critical value [13,51-53]. Above this level the need for energy storage dramatically increases (Figure 7) as evidenced by most studies. Below $40-50 \%$ of VRE share the storage fraction increases basically linearly, but most studies gave diverging storage fraction values for the 50-100\% VRE share. With the relationship created, fraction values up to a VRE penetration of $95 \%$ were analyzed (Figure 7). Based on the reviewed studies, the figures given for the recommended storage capacities at an all European level in the case of generating $100 \%$ of the annual demand by using RES show far too great a variation to be reliable (Table 5) $[35,37,47,49,70,75,76]$; therefore, a VRE penetration of $100 \%$ was not examined in this research. With the help of a polynomial regression model, an equation that describes the average European storage fraction related to the percentage of gross VRE electricity generation was developed. To build the equation (Equation (1)) that best models the storage fraction as a function of VRE share in consumption, the equation takes into consideration the joint slopes of source [22] for VRE shares below $45 \%$ and [47,50] above $45 \%$, resulting in the final figures of storage fractions as shown in the figure below. With Equation number 1 (Table 6), it is possible to determine the energy storage capacity volumes of electricity (at stationary storage systems) at the European level, assuming appropriate demand-side management, smart market regulations, advanced weather forecasting systems, and continuous, ideal European network development to maintain secure 
electricity supplies through balancing. The R-square and adjusted R-square values of the MATLAB model derived from the input data are 1.



Figure 7. Result of the average European storage fraction analysis.

Table 6. Result of the European storage fraction analysis.

\begin{tabular}{cc}
\hline Description & Equation \\
\hline \multirow{2}{*}{ Equation (1), storage fraction [\%] } & Storage fraction $=p_{1} V R E^{8}+p_{2} V R E^{7}+p_{3} V R E^{6}+p_{4} V R E^{5}$ \\
& $+p_{5} V R E^{4}+p_{6} V R E^{3}+p_{7} V R E^{2}+p_{8} V R E+p_{9}$ \\
\hline \multirow{2}{*}{$p_{\text {i parameter values }}$} & $p_{1}=-3.758^{-14} ; p_{2}=-1.327^{-11} ; p_{3}=1.818^{-09} ; p_{4}=-1.234^{-07} ;$ \\
& $p_{5}=4.443^{-06} ; p_{6}=-8.163^{-05} ; p_{7}=5.844^{-04} ;$ \\
& $p_{8}=1.646^{-03} ; p_{8}=3.687^{-04}$ \\
\hline
\end{tabular}

\subsection{Determination of the European Storage Power Capacity}

It should be noted that there is no unified solution for determining the necessary future storage power capacity size requirements in Europe, but there are some well-defined ranges. Due to the lack of data, it is the studies $[22,47,50,77]$ that can provide adequate information on the necessary future storage capacity requirements needed for balancing the European grid. In these sources, the $16-48 \%$ and the $80 \%$ VRE penetration ranges can be determined [22,47,50,77]. In the case of a European annual demand of 4900 TWh and $80 \%$ VRE integration, a $125 \mathrm{GW}$ storage power capacity is recommended for grid balancing. In the model, the value of $125 \mathrm{GW}$ was adjusted proportionally to the annual demand values of the 2040 ENTSO-E scenarios [22,47,50,77]. The starting point of the modeling was the power capacity context of [22] up to $45 \%$ of VRE penetration, then due to the lack of data, polynomial regression models were applied to the GW values of VRE gross electricity generation of $45-80 \%$. The relationship is confirmed by the work of Cebulla et al. [49] and the results approximate the values of 'balanced' and 'wind +' of [49] (the PV and wind ratios between installed capacities for the first category were 2:1-1:1.5, while the second category value was 1:1.5). Based on this, the power capacity requirements for the VRE objectives of the ENTSO-E scenarios were determined (Figure 8). In addition, the theoretical maximum VRE integration potentials of the summarized European power capacity of all storage technologies were also determined. 


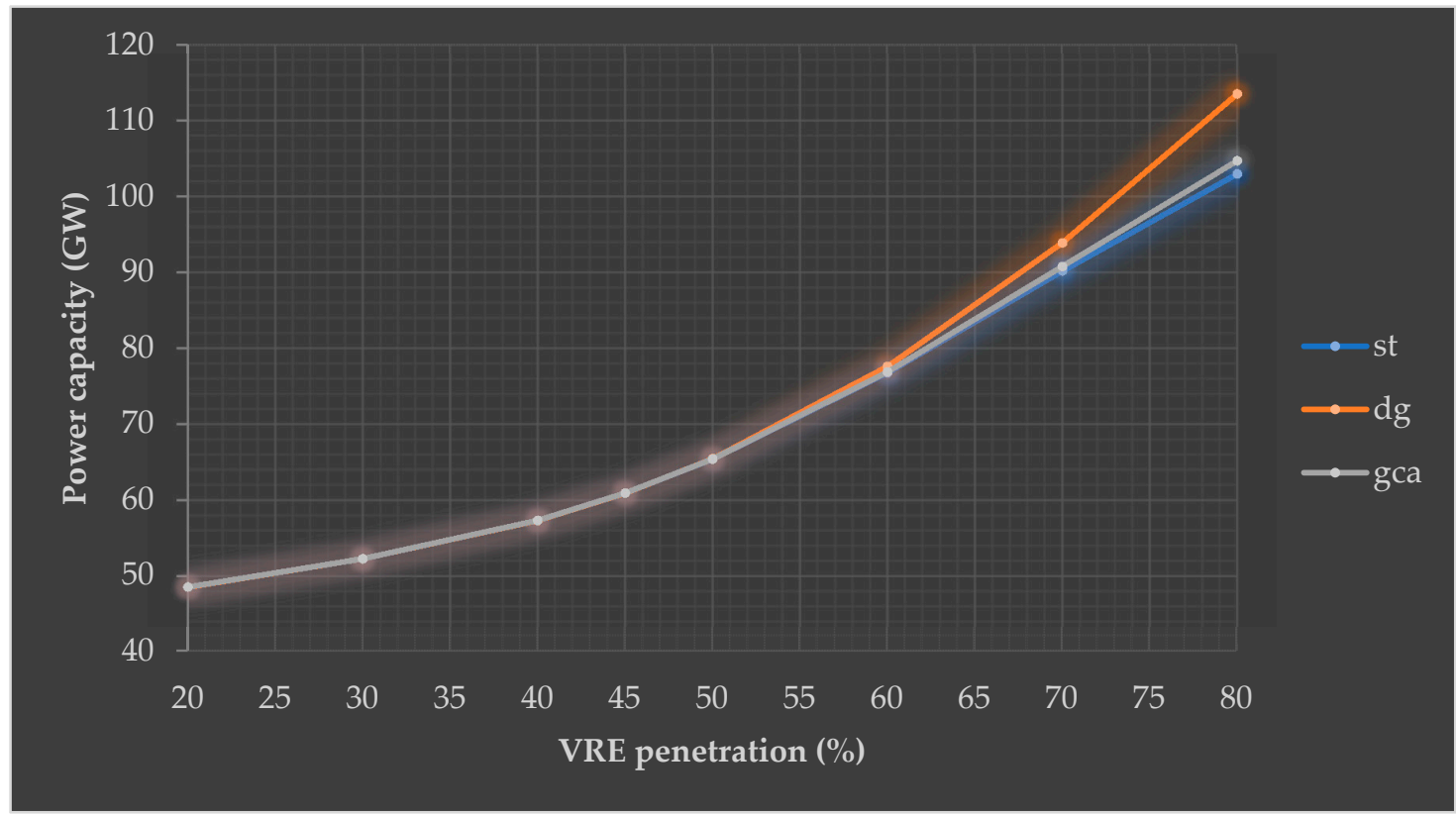

Figure 8. European power capacity requirement analysis results based on different VRE penetration levels of the 2040 ENTSO-E scenarios.

\subsection{European Variable Renewable Energy Integration Possibilities}

The power capacity of PHS was calculated on the basis of the ENTSO-E ST, DG, and GCA scenarios. From the energy capacity input data of $[11,40,42-44]$ the sources, the PHS energy capacity was estimated by linear change due to lack of data (Tables 7 and 8). The International Renewable Energy Agency (IRENA) published a comprehensive study [10] on the future of energy storage trends, cost, and markets. This report breaks down the electricity storage energy capacity growth by storage technology according to four scenarios in 2030. However, the scenarios differ significantly and IRENA'S reference data were taken into account for the calculations. Considering the IRENA, the Global Energy Storage Database (DOE) studies, and the ENTSO-E Ten Years Network Development Plan 2018 Storage project database $[9,10,78]$, it was assumed that the estimated European power capacity of other storage technologies will be $5 \%$ (scenario 1) and $25 \%$ (scenario 2) compared to the PHS values in 2040, and the average charge/discharge period was assumed as (other storage technologies) $8 / 8 \mathrm{~h}$ (scenario 1 ) and 12/12 h (scenario 2) (Tables 7 and 8).

Table 7. Power capacity and energy storage capacity results of the European energy storage systems in 2040, based on [9-11,27,40,42-44,78,79], scenario 1 .

\begin{tabular}{|c|c|c|}
\hline Year & 2040, DG & 2040, GCA \\
\hline Power capacity of PHS [GW] & 58 & 76 \\
\hline Estimated energy storage capacity, PHS [GWh] & 3500 & 3900 \\
\hline $\begin{array}{l}\text { Estimated European power capacity of other } \\
\text { storage technologies, scenario } 1[\mathrm{GW}]\end{array}$ & 2.9 & 3.8 \\
\hline $\begin{array}{l}\text { Estimated energy storage capacity, other } \\
\text { storage technologies, scenario } 1 \text { [GWh] }\end{array}$ & 23,2 & 30.4 \\
\hline $\begin{array}{l}\text { Summarized European power capacity of all } \\
\text { storage technologies, scenario } 1[\mathrm{GW}]\end{array}$ & 60.9 & 79.8 \\
\hline $\begin{array}{l}\text { Summarized energy storage capacity of all } \\
\text { storage technologies, scenario } 1 \text { [GWh] }\end{array}$ & 3523.2 & 3930.4 \\
\hline
\end{tabular}


Table 8. Power capacity and energy storage capacity results of the European energy storage systems in 2040, based on [9-11,27,40,42-44,78,79], scenario 2 .

\begin{tabular}{|c|c|c|}
\hline Year & 2040, DG & 2040, GCA \\
\hline Power capacity of PHS [GW] & 58 & 76 \\
\hline Estimated energy storage capacity, PHS [GWh] & 3500 & 3900 \\
\hline $\begin{array}{l}\text { Estimated European power capacity of other } \\
\text { storage technologies, scenario } 2[\mathrm{GW}]\end{array}$ & 14.5 & 19 \\
\hline $\begin{array}{l}\text { Estimated energy storage capacity, other } \\
\text { storage technologies, scenario } 2 \text { [GWh] }\end{array}$ & 174 & 228 \\
\hline $\begin{array}{l}\text { Summarized European power capacity of all } \\
\text { storage technologies, scenario } 2 \text { [GW] }\end{array}$ & 72.5 & 95 \\
\hline $\begin{array}{l}\text { Summarized energy storage capacity of all } \\
\text { storage technologies, scenario } 2 \text { [GWh] }\end{array}$ & 3674 & 4128 \\
\hline
\end{tabular}

From the electricity demand and the VRE penetration in the ENTSO-E ST, DG, and GCA scenarios, the energy storage capacity requirements and the storage fraction requirements were calculated by using Equation (1) (Table 9). Based on the analyzed scenarios, the fraction values were between $0.033 \%$ and $0.166 \%$, which would mean $1.35-6.82$ TWh energy storage capacities. In addition, the power capacity requirements of the energy storage systems of the three scenarios for the VRE integration would be in the range of $57-76 \mathrm{GW}$.

Table 9. Results related to the European storage power capacity and energy storage capacity requirements in 2040 .

\begin{tabular}{cccc}
\hline Year & 2040, ST & 2040, DG & 2040, GCA \\
\hline Electricity demand [TWh] & 4030 & 4450 & 4100 \\
\hline ENTSO-E, maximum peak load [GW] & 650 & 730 & 690 \\
\hline $\begin{array}{c}\text { Annual VRE gross electricity generation } \\
\text { compared to the demand [\%] }\end{array}$ & 39.7 & 50.6 & 59.3 \\
\hline $\begin{array}{c}\text { Required storage fraction for the scenarios, } \\
\text { based on equation 1 [\%] }\end{array}$ & 0.033 & 0.057 & 6819 \\
\hline $\begin{array}{c}\text { Required energy storage capacity for the } \\
\text { scenarios, based on equation 1 [GWh] }\end{array}$ & 1348 & 2518 & 76 \\
\hline $\begin{array}{c}\text { Required storage power capacity to the } \\
\text { scenarios, based on the logic of Figure 8 [GW] }\end{array}$ & 57 & 66 & \\
\hline
\end{tabular}

It was examined whether the VRE penetration targets of the ENTSO-E scenarios would be feasible considering the estimated storage power capacity and the energy capacity of stationary storage systems based on the approaches of scenario 1 and 2. It was also determined whether the power capacity or the energy storage capacity is the limiting factor in terms of successful VRE integration. Based on the results, we came to the conclusion that due to the need for a secure electricity supply both factors are equally important for successful VRE integration (Figure 9). The results showed that achieving a minimum of approximately $45-50 \%$ VRE penetration integration could be a realistic target in the European power grid sector until 2040. The ENTSO-E ST and DG scenarios appear to be rational goals. For the GCA scenario, the 55\% VRE penetration rate seems to be feasible compared to the 59\% target. According to the results, energy storage market developments and regulations that motivate the increased use of energy storage systems are of great importance for a successful European solar and wind energy integration. 


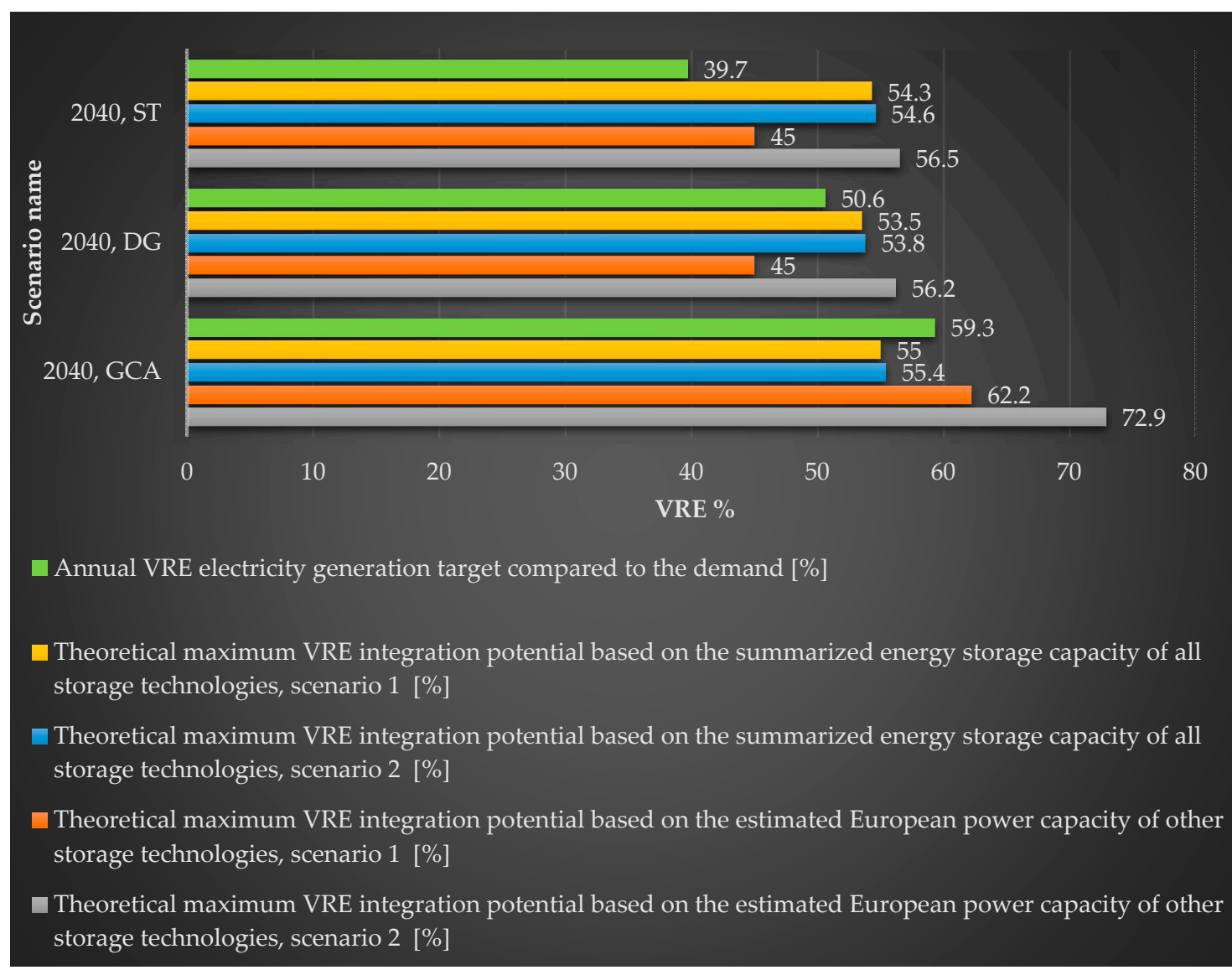

Figure 9. The feasibility of the European VRE integration target based on the various scenarios.

\section{Conclusions}

This study examined the European variable renewable energy integration challenges related to the power capacity and energy capacity of stationary storage technologies. It also analyzed and presented the feasibility of the European VRE electricity generation targets and the theoretical maximum related to the 2040 scenarios. The determination of the storage fractions, the power capacity, and the energy storage capacity were modelled in a new context. Based on the results we came to the conclusion that due to the requirement of a secure electricity supply, all factors are equally important for successful VRE integration. The results showed that achieving a minimum of approximately $45-50 \%$ VRE penetration unitl 2040 could be a realistic target in the European energy grid sector. The ENTSO-E ST and DG scenarios appear to be rational goals. For the GCA scenario, a 55\% VRE penetration rate seems feasible compared to the 59\% target. For the success of European VRE integration, energy storage market developments and regulations that motivate the increased use of energy storage systems are crucial.

Author Contributions: H.Z. was mainly responsible for the technical and modelling aspects, and conceived and designed the manuscript. All authors contributed equally in the analysis of the data and the writing and revision of the manuscript.

Acknowledgments: We acknowledge the financial support of Széchenyi 2020 under the EFOP-3.6.1-16-2016-00015. Conflicts of Interest: The authors declare no conflict of interest. 


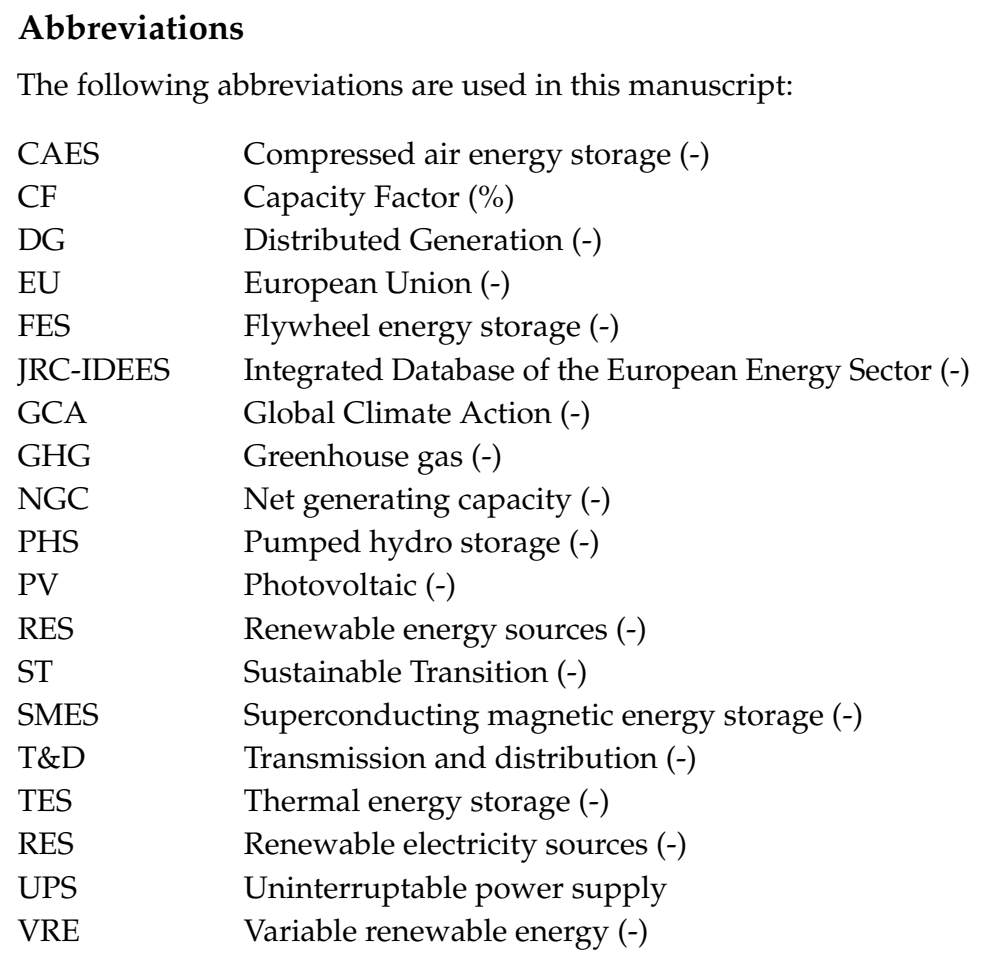

\section{References}

1. Zafar, R.; Mahmood, A.; Razzaq, S.; Ali, W.; Naeem, U.; Shehzad, K. Prosumer based energy management and sharing in smart grid. Renew. Sustain. Energy Rev. 2018, 82, 1675-1684. [CrossRef]

2. Zame, K.K.; Brehm, C.A.; Nitica, A.T.; Richard, C.L.; Schweitzer, G.D., III. Smart grid and energy storage: Policy recommendations. Renew. Sustain. Energy Rev. 2018, 82, 1646-1654. [CrossRef]

3. Kordmahaleh, A.A.; Naghashzadegan, M.; Javaherdeh, K.; Khoshgoftar, M. Design of a 25 MWe Solar Thermal Power Plant in Iran with Using Parabolic Trough Collectors and a Two-Tank Molten Salt Storage System. Int. J. Photoenergy 2017, 2017, 4210184. [CrossRef]

4. Noman, A.M.; Addoweesh, K.E.; Alolah, A.I. Simulation and Practical Implementation of ANFIS-Based MPPT Method for PV Applications Using Isolated Ćuk Converter. Int. J. Photoenergy 2017, 2017, 3106734. [CrossRef]

5. Daliento, S.; Chouder, A.; Guerriero, P.; Pavan, A.M.; Mellit, A.; Moeini, R.; Tricoli, P. Monitoring, Diagnosis, and Power Forecasting for Photovoltaic Fields: A Review. Int. J. Photoenergy 2017, 2017, 1356851. [CrossRef]

6. Cucchiella, F.; D'Adamo, I. A Multicriteria Analysis of Photovoltaic Systems: Energetic, Environmental, and Economic Assessments. Int. J. Photoenergy 2015, 2015, 627454. [CrossRef]

7. D'Adamo, I.; Miliacca, M.; Rosa, P. Economic Feasibility for Recycling of Waste Crystalline Silicon Photovoltaic Modules. Int. J. Photoenergy 2017, 2017, 4184676. [CrossRef]

8. Fathima, A.H.; Palanisamy, K. Energy Storage Systems for Energy Management of Renewables in Distributed Generation Systems. In Energy Management of Distributed Generation Systems; InTech: London, UK, 2016.

9. Sandia National Laboratories. DOE Global Energy Storage Database. Available online: https://www. energystorageexchange.org/projects/data_visualization (accessed on 2 March 2019).

10. International Renewable Energy Agency. Electricity Storage and Renewables: Costs and Markets to 2030; International Renewable Energy Agency: Abu Dhabi, UAE, 2017.

11. Gimeno-Gutiérrez, M.; Lacal-Arántegui, R. Assessment of the European potential for pumped hydropower energy storage based on two existing reservoirs. Renew. Energy 2015, 75, 856-868. [CrossRef]

12. The Conversation Trust (UK) Limited. As Nuclear Power Plants Close, States Need to Bet Big on Energy Storage. Available online: https://theconversation.com/as-nuclear-power-plants-close-states-need-to-betbig-on-energy-storage-62032 (accessed on 26 September 2018).

13. Schill, W.-P. Residual load, renewable surplus generation and storage requirements in Germany. Energy Policy 2014, 73, 65-79. [CrossRef] 
14. Luo, X.; Wang, J.; Dooner, M.; Clarke, J. Overview of current development in electrical energy storage technologies and the application potential in power system operation. Appl. Energy 2015. [CrossRef]

15. Fraunhofer Institute for Solar Energy Systems ISE. Annual Report 2016/2017; Fraunhofer institute for solar energy systems ISE: Freiburg, Germany, 2017; pp. 1-88.

16. Zsiborács, H.; Pályi, B.; Pintér, G.; Popp, J.; Balogh, P.; Gabnai, Z.; Pető, K.; Farkas, I.; Baranyai, N.H.; Bai, A. Technical-economic study of cooled crystalline solar modules. Sol. Energy 2016, 140. [CrossRef]

17. Renewables 2018 Global Status Report-REN21; REN21: Paris, France, 2018.

18. Enjavi-Arsanjani, M.; Hirbodi, K.; Yaghoubi, M. Solar Energy Potential and Performance Assessment of CSP Plants in Different Areas of Iran. Energy Procedia 2015, 69, 2039-2048. [CrossRef]

19. Statista, I. Cumulative Solar Photovoltaic Capacity Globally as of 2017, by Select Country (in Gigawatts). Available online: https://www.statista.com/statistics/264629/existing-solar-pv-capacity-worldwide/ (accessed on 12 September 2018).

20. European Commission. Energy Storage-The Role of Electricity; European Commission: Brussels, Belgium, 2017.

21. Rodríguez, R.A.; Becker, S.; Andresen, G.B.; Heide, D.; Greiner, M. Transmission needs across a fully renewable European power system. Renew. Energy 2014, 63, 467-476. [CrossRef]

22. Bertsch, J.; Growitsch, C.; Lorenczik, S.; Nagl, S. Flexibility in Europe's power sector-An additional requirement or an automatic complement? Energy Econ. 2016, 53, 118-131. [CrossRef]

23. Cho, A. Energy's tricky tradeoffs. Science 2010, 329, 786-787. [CrossRef] [PubMed]

24. Jacobson, M.Z.; Delucchi, M.A. Providing all global energy with wind, water, and solar power, Part I: Technologies, energy resources, quantities and areas of infrastructure, and materials. Energy Policy 2011, 39, 1154-1169. [CrossRef]

25. Delucchi, M.A.; Jacobson, M.Z. Providing all global energy with wind, water, and solar power, Part II: Reliability, system and transmission costs, and policies. Energy Policy 2011, 39, 1170-1190. [CrossRef]

26. Czisch, G. Szenarien zur Zukünftigen Stromversorgung, Kostenoptimierte Variationen zur Versorgung Europas und Seiner Nachbarn mit Strom aus Erneuerbaren Energien. Ph.D. Thesis, Universitat Kassel, Kassel, Germany, 2005.

27. ENTSO-E. TYNDP 2018—Scenario Report. Available online: https://tyndp.entsoe.eu/tyndp2018/scenarioreport/ (accessed on 12 April 2019).

28. Czisch, G.; Giebel, G. Realisable Scenarios for a Future Electricity Supply Based 100\% on Renewable Energies in: Energy Solutions for Sustainable Development: Proceedings of the Risø International Energy Conference 2007; [...took place 22-24 May 2007]; Risø National Laboratory: Roskilde, Denmark, 2007; ISBN 9788755036031.

29. Kempton, W.; Pimenta, F.M.; Veron, D.E.; Colle, B.A. Electric power from offshore wind via synoptic-scale interconnection. Proc. Natl. Acad. Sci. USA 2010, 107, 7240-7245. [CrossRef]

30. Schaber, K.; Steinke, F.; Hamacher, T. Transmission grid extensions for the integration of variable renewable energies in Europe: Who benefits where? Energy Policy 2012, 43, 123-135. [CrossRef]

31. Schaber, K.; Steinke, F.; Mühlich, P.; Hamacher, T. Parametric study of variable renewable energy integration in Europe: Advantages and costs of transmission grid extensions. Energy Policy 2012, 42, 498-508. [CrossRef]

32. Widen, J. Correlations Between Large-Scale Solar and Wind Power in a Future Scenario for Sweden. IEEE Trans. Sustain. Energy 2011, 2, 177-184. [CrossRef]

33. Aboumahboub, T.; Schaber, K.; Tzscheutschler, P.; Hamacher, T. Optimal Configuration of a Renewable-based Electricity Supply Sector. WSEAS Trans. POWER Syst. 2010, 5, 120-129.

34. Yao, R.; Steemers, K. A method of formulating energy load profile for domestic buildings in the UK. Energy Build. 2005, 37, 663-671. [CrossRef]

35. Heide, D.; von Bremen, L.; Greiner, M.; Hoffmann, C.; Speckmann, M.; Bofinger, S. Seasonal optimal mix of wind and solar power in a future, highly renewable Europe. Renew. Energy 2010, 35, 2483-2489. [CrossRef]

36. Heide, D.; Greiner, M.; von Bremen, L.; Hoffmann, C. Reduced storage and balancing needs in a fully renewable European power system with excess wind and solar power generation. Renew. Energy 2011, 36, 2515-2523. [CrossRef]

37. Rasmussen, M.G.; Andresen, G.B.; Greiner, M. Storage and balancing synergies in a fully or highly renewable pan-European power system. Energy Policy 2012, 51, 642-651. [CrossRef]

38. Hedegaard, K.; Meibom, P. Wind power impacts and electricity storage-A time scale perspective. Renew. Energy 2012, 37, 318-324. [CrossRef] 
39. Argyrou, M.C.; Christodoulides, P.; Kalogirou, S.A. Energy storage for electricity generation and related processes: Technologies appraisal and grid scale applications. Renew. Sustain. Energy Rev. 2018, 94, 804-821. [CrossRef]

40. PANNON Pro Innovations Ltd. Practical Experiences of PV and Storage Systems. Available online: https://klimainnovacio.hu/en/pannon-pro-innovations (accessed on 2 February 2018).

41. Entso-E. Statistics and Data-Electricity in Europe. Available online: https://www.entsoe.eu/publications/ statistics-and-data/ (accessed on 11 April 2019).

42. Union of the Electricity Industry-EURELECTRIC. Hydro in Europe: Powering Renewables Full Report; EURELECTRIC: Brussels, Belgium, 2011.

43. Mantzos, L.; Matei, N.A.; Mulholland, E.; Rózsai, M.; Tamba, M.; Wiesenthal, T. Joint Research Centre Data Catalogue, JRC-IDEES 2015. Available online: http://data.jrc.ec.europa.eu/dataset/jrc-10110-10001 (accessed on 11 March 2019).

44. International Hydropower Association. Pumped Storage Tracking Tool. Available online: https://www. hydropower.org/hydropower-pumped-storage-tool (accessed on 19 December 2018).

45. International Hydropower Association. Hydropower Status Report, 2018; International Hydropower Association: London, UK, 2018.

46. European Academies Science Advisory Council. ea sac Science Advice for the Benefit of Europe Valuing Dedicated Storage in Electricity Grids; European Academies Science Advisory Council: Halle (Saale), Germany, 2017.

47. Blanco, H.; Faaij, A. A review at the role of storage in energy systems with a focus on Power to Gas and long-term storage. Renew. Sustain. Energy Rev. 2018, 81, 1049-1086. [CrossRef]

48. ENTSO-E. Europe Power System 2040: Completing the Map \& Assessing the Cost of Non-Grid. Available online: https://tyndp.entsoe.eu/tyndp2018/power-system-2040/ (accessed on 12 April 2019).

49. Cebulla, F.; Haas, J.; Eichman, J.; Nowak, W.; Mancarella, P. How much electrical energy storage do we need? A synthesis for the U.S., Europe, and Germany. J. Clean. Prod. 2018, 181, 449-459. [CrossRef]

50. European Commission. Roadmap 2050: A practical Guide to a Prosperous, Low-Carbon Europe; European Climate Foundation (ECF): AM Den Haag, The Netherlands, 2010.

51. Kondziella, H.; Bruckner, T. Flexibility requirements of renewable energy based electricity systems-A review of research results and methodologies. Renew. Sustain. Energy Rev. 2016, 53, 10-22. [CrossRef]

52. Agora Energiewende. Stromspeicher in der Energiewende; Agora Energiewende: Berlin, Germany, 2014.

53. Fraunhofer Institute for Solar Energy Systems. Roadmap Speicher-Speicherbedarf für Erneuerbare Energien Speicheralternativen-Speicheranreiz—Überwindung rechtlicher Hemmnisse; Endbericht: Freiburg, Germany, 2014.

54. D5.2-SPAIN, Overview of Current Status and Future Development Scenarios of the Electricity System, and Assessment of the Energy Storage Needs; stoRE: Munich, Germany, 2013.

55. de Boer, H.S.; Grond, L.; Moll, H.; Benders, R. The application of power-to-gas, pumped hydro storage and compressed air energy storage in an electricity system at different wind power penetration levels. Energy 2014, 72, 360-370. [CrossRef]

56. Inage, S. Prospects for Large-Scale Energy Storage in Decarbonised Power Grids; International Energy Agency: Paris, France, 2009.

57. Strbac, G.; Aunedi, M.; Pudjianto, D.; Djapic, P.; Teng, F.; Sturt, A.; Jackravut, D.; Sansom, R.; Yufit, V.; Brandon, N. Strategic Assessment of the Role and Value of Energy Storage Systems in the UK Low Carbon Energy Future; Imperial College London: London, UK, 2012.

58. Power System Overview and RES Integration, Ireland; stoRE: Munich, Germany, 2013.

59. Overview of the Electricity Supply System and an Estimation of Future Energy Storage Needs, Germany; stoRE: Munich, Germany, 2013.

60. Ludig, S.; Haller, M.; Schmid, E.; Bauer, N. Fluctuating renewables in a long-term climate change mitigation strategy. Energy 2011, 36, 6674-6685. [CrossRef]

61. D5.1-GREECE, Overview of the Electricity System Status and its Future Development Scenarios-Assessment of the Energy Storage Infrastructure Needs; stoRE: Munich, Germany, 2013.

62. Assessment of the Future Energy Storage Needs of Austria for Integration of Variable RES-E Generation, Deliverable 5.1-Austria; stoRE: Munich, Germany, 2013.

63. Pfenninger, S.; Keirstead, J. Renewables, nuclear, or fossil fuels? Scenarios for Great Britain's power system considering costs, emissions and energy security. Appl. Energy 2015, 152, 83-93. [CrossRef] 
64. Belderbos, A.; Delarue, E.; D'haeseleer, W. Possible role of power-to-gas in future energy systems. In Proceedings of the 2015 12th International Conference on the European Energy Market (EEM), Lisbon, Portugal, 19-22 May 2015; pp. 1-5.

65. Overview of Current Status and Future Development Scenarios of the Electricity System in Denmark-Allowing Integration of Large Quantities of Wind Power; stoRE: Munich, Germany, 2013.

66. Doetsch, C.; Droste-Franke, B.; Perrin, M. Electric Energy Storage, Future Energy Storage Demand; International Energy Agency: Paris, France, 2015.

67. Bertuccioli, L.; Chan, A.; Hart, D.; Lehner, F.; Madden, B.; Standen, E. Development of Water Electrolysis in the European Union, Final Report; Fuel cells and hydrogen Joint Undertaking: Lausann, Switzerland; Cambridge, UK, 2014.

68. Moeller, C.; Meiss, J.; Mueller, B.; Hlusiak, M.; Breyer, C.; Kastner, M.; Twele, J. Transforming the electricity generation of the Berlin-Brandenburg region, Germany. Renew. Energy 2014, 72, 39-50. [CrossRef]

69. Connolly, D.; Lund, H.; Mathiesen, B.V.; Leahy, M. The first step towards a $100 \%$ renewable energy-system for Ireland. Appl. Energy 2011, 88, 502-507. [CrossRef]

70. Aboumahboub, T.; Schaber, K.; Tzscheutschler, P.; Hamacher, T. Optimization of the utilization of renewable energy sources in the electricity sector. In Proceedings of the EE'10 Proceedings of the 5th IASME/WSEAS International Conference on Energy \& Environment, Cambridge, UK, 23-25 February 2010; pp. 196-204.

71. Krakowski, V.; Assoumou, E.; Mazauric, V.; Maïzi, N. Feasible path toward 40-100\% renewable energy shares for power supply in France by 2050: A prospective analysis. Appl. Energy 2016, 171, 501-522. [CrossRef]

72. Weitemeyer, S.; Kleinhans, D.; Vogt, T.; Agert, C. Integration of Renewable Energy Sources in future power systems: The role of storage. Renew. Energy 2015, 75, 14-20. [CrossRef]

73. Centre for Alternative Technology. Zero Carbon: Rethinking the Future-Centre for Alternative Technology. Available online: https://www.cat.org.uk/info-resources/zero-carbon-britain/research-reports/zero-carbonrethinking-the-future/ (accessed on 12 April 2019).

74. Anagnostopoulos, J.S.; Papantonis, D.E. Study of pumped storage schemes to support high RES penetration in the electric power system of Greece. Energy 2012, 45, 416-423. [CrossRef]

75. Sauer, D.U.; Moser, A.; Leuthold, M.; Cai, Z.; Chen, H.; Alvarez, R.; Moos, M.; Thien, T. Storage Demand in a 100\%-RES-Power System for Europe with Different PV-Installation Levels. In 28th European Photovoltaic Solar Energy Conference and Exhibition; WIP: Paris, France, 2013; pp. 4261-4265.

76. Steinke, F.; Wolfrum, P.; Hoffmann, C. Grid vs. storage in a 100\% renewable Europe. Renew. Energy 2013, 50, 826-832. [CrossRef]

77. European Climate Foundation. Roadmap 2050-Technical \& Economic Analysis—Full Report. Available online: http://www.roadmap2050.eu/project/roadmap-2050 (accessed on 27 September 2018).

78. ENTSO-E. TYNDP 2018 Storage Project Sheets. Available online: https://tyndp.entsoe.eu/tyndp2018/projects/ storage_projects (accessed on 1 May 2019).

79. International Renewable Energy Agency (IRENA). Renewable Energy Capacity Statistics 2017; IRENA: Abu Dhabi, UAE, 2017.

(C) 2019 by the authors. Licensee MDPI, Basel, Switzerland. This article is an open access article distributed under the terms and conditions of the Creative Commons Attribution (CC BY) license (http://creativecommons.org/licenses/by/4.0/). 